
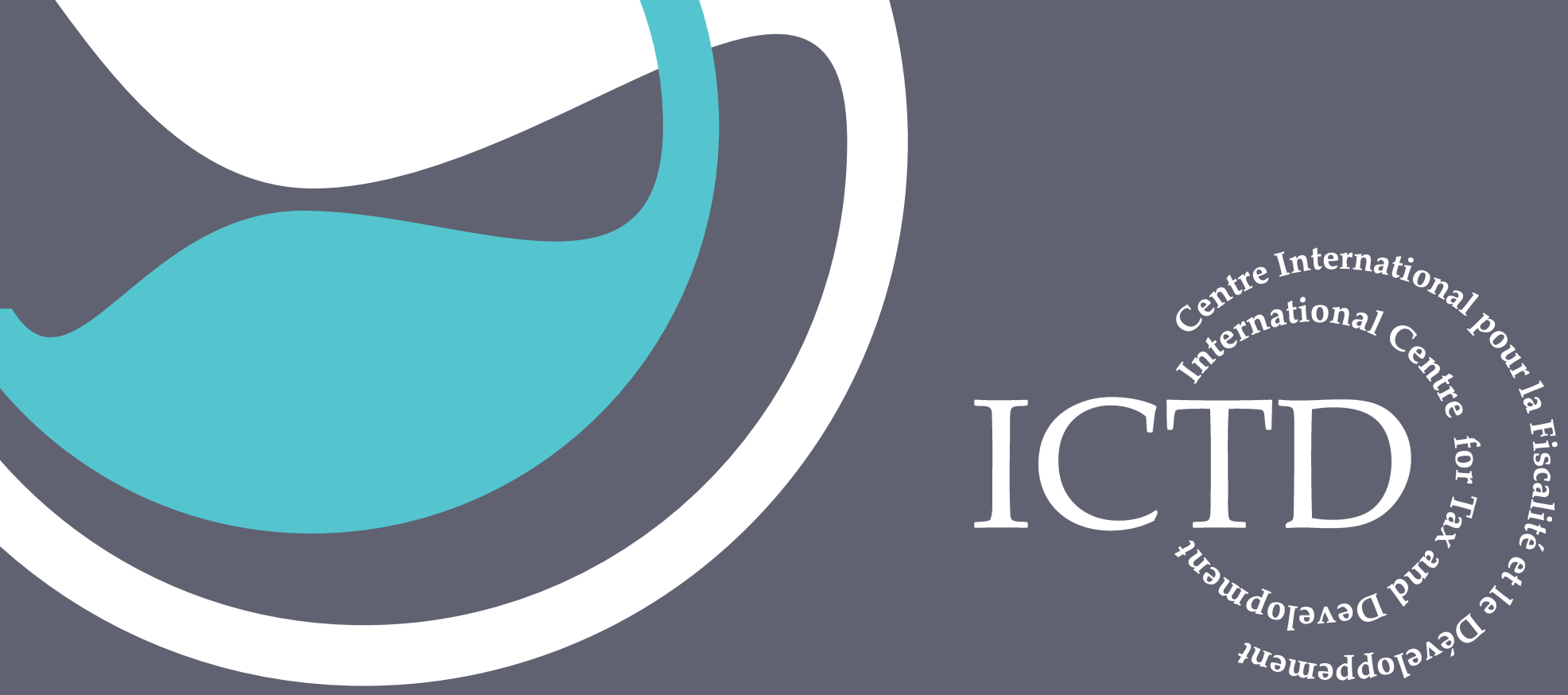

Working Paper 65

\title{
The Political Economy of Iong-Term Revenue Decline in Sri Lanka
}

Mick Moore

February 2017 
ICTD Working Paper 65

\section{The Political Economy of Long-Term Revenue Decline in Sri Lanka}

Mick Moore

February 2017 
The International Centre for Tax and Development is a global policy research network that deals with the political economy of taxation policies and practices in relation to the poorer parts of the world. Its operational objectives are to generate and disseminate relevant knowledge to policymakers and to mobilise knowledge in ways that will widen and deepen public debate about taxation issues within poorer countries. Its ultimate objective is to contribute to development in the poorer parts of the world and help make taxation policies more conducive to pro-poor economic growth and good governance. The ICTD's research strategy and organisational structures are designed to bring about productive interaction between established experts and new stakeholders.

The ICTD is funded with UK aid from the UK Government, and by the Norwegian Agency for Development Cooperation (Norad), a directorate under the Norwegian Ministry of Foreign Affairs (MFA); however, the views expressed herein do not necessarily reflect the UK and Norwegian Governments' official policies.

The Political Economy of Long-Term Revenue Decline in Sri Lanka

Mick Moore

ICTD Working Paper 65

First published by the Institute of Development Studies in February 2017

(c) Institute of Development Studies 2017

ISBN: 978-1-78118-349-6

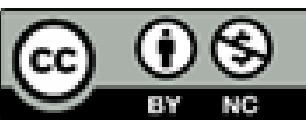

This is an Open Access paper distributed under the terms of the Creative Commons Attribution Non Commercial 4.0 International license, which permits downloading and sharing provided the original authors and source are credited - but the work is not used for commercial purposes. http://creativecommons.org/licenses/by-nc/4.0/legalcode

Readers are encouraged to quote and reproduce material from this series. In return, ICTD requests due acknowledgment and quotes to be referenced as above.

\section{Available from:}

The International Centre for Tax and Development at the Institute of Development Studies, Brighton BN1 9RE, UK

Tel: +44 (0) 1273606261

Email: info@ictd.ac.uk

Web: www.ictd/en/publications

IDS is a charitable company limited by guarantee and registered in England

Charity Registration Number 306371

Charitable Company Number 877338 


\title{
The Political Economy of Long-Term Revenue Decline in Sri Lanka
}

\author{
Mick Moore
}

\section{Summary}

From the 1950s to the 1980s, Sri Lankan governments collected a high proportion of Gross Domestic Product (GDP) in taxes. They spent most of that money on mass provision of health and education services, and subsidised food. Sri Lanka was a model welfare state, with unusually high human development indicators. Contemporary Sri Lankan governments spend very little on their poor citizens. A major reason is that since 1990 the proportion of GDP collected in tax revenue has steadily declined, such that it is now at unusually low levels. Internal conflict, although almost endemic, does not explain declining tax collection. The decline results from a continuous series of policy decisions to exempt wealthier people, businesses, incomes and assets from taxes. This paper analyses the more identifiable political and institutional processes through which the political preferences of the wealthy and powerful were translated into low revenue collection. They are: the declining power of popular forces (notably programmatic political parties and trade unions); the emergence of foreign aid and loans as an alternative to domestic revenue mobilisation; the institutionalisation of pressure to exempt the private sector from taxes; powerful executive presidents who undermined or dispensed with the authority of ministers of finance; and a political and institutional lock-in to a high dependence on taxes levied on a declining sector of the economy - imports - and to the Customs Department that collects them.

Keywords: taxation; Sri Lanka; history; Customs Department; Inland Revenue Department; inequality.

Mick Moore is a Professorial Fellow at the Institute of Development Studies, and the founding Chief Executive Officer of the International Centre for Tax and Development, UK. 


\section{Contents}

Summary 3

Acknowledgements $\quad 5$

Acronyms

Introduction: taxing fashions $\quad 6$

$1 \quad$ An unprecedented and puzzling decline $\quad 7$

2 Why was the tax take high in the mid-twentieth century?

$3 \quad$ Explaining decreasing revenue collection $\quad 12$

$4 \quad$ Changing electoral pressures $\quad 15$

$5 \quad$ 'Easy' non-tax funding $\quad 17$

$6 \quad$ Institutionalised pressure for tax exemptions 19

$\begin{array}{lll}7 & \text { Absentee finance ministers } & 20\end{array}$

$8 \quad$ Lock-in to import taxes 22

$9 \quad$ Concluding comments $\quad 26$

$\begin{array}{lr}\text { References } & 29\end{array}$

Tables

Table 1

Table 2

Summary economic and fiscal statistics, 5-year average

Table 3

Sources of government revenue (\%), 1970/1-2015, 5-year average

Major sources of government revenue (\% of total), 1938/9 and

2011-14 


\section{Acknowledgements}

I am very grateful to the following people and institutions for discussion of the issues in this paper and/or comments on earlier drafts: Joanne Asquith, Sunil Bastian, Richard Bird, Indrajit Coomaraswamy, Nishan de Mel, Mike Durst, N. Gajendran, Godfrey Gunatilleke, Murtaza Jaferjee, Saman Kelegama, Dharmasena Koditawakku, Waziona Ligomeka, Michael Lipton, Giulia Mascagni, Nimal Sanderatne, D. D. M. Waidyasekera, Gamini Wickremesinghe, Anushka Wijesinghe, and various staff members who participated in meetings in Colombo at the Central Bank, the Customs Department, the Inland Revenue Department, the Institute of Policy Studies, the International Monetary Fund (IMF), the Treasury, and the World Bank.

\section{Acronyms}

$\begin{array}{ll}\text { BTT } & \text { Business Turnover Tax } \\ \text { EPZ } & \text { Export Processing Zone } \\ \text { FEEC } & \text { Foreign Exchange Entitlement Certificate } \\ \text { GCEC } & \text { Greater Colombo Economic Commission } \\ \text { GDP } & \text { Gross Domestic Product } \\ \text { GMOA } & \text { General Medical Officers' Association } \\ \text { GNP } & \text { Gross National Product } \\ \text { GST } & \text { Goods and Services Tax } \\ \text { IMF } & \text { International Monetary Fund } \\ \text { IRD } & \text { Inland Revenue Department } \\ \text { JVP } & \text { Janatha Vimukthi Peramuna } \\ \text { SLFP } & \text { Sri Lanka Freedom Party } \\ \text { UNP } & \text { United National Party } \\ \text { VAT } & \text { Value Added Tax }\end{array}$




\section{Introduction: taxing fashions}

Governments of poorer countries should aim to raise a higher proportion of Gross National Product (GNP) in tax revenue. ${ }^{1}$ Every government should aim to collect at least 20 per cent of GNP. These are the messages that the international community has been sending out in recent years. ${ }^{2}$ Taxing has become internationally fashionable. Sri Lankan governments have, however, been following their own, very different, fiscal fashions. They were once quite avid taxers. For the first 30 years after independence in 1948, the ratio of government revenue collection to GDP - a figure that I will henceforth term the 'tax take' - oscillated around a long-term average of 21 per cent. ${ }^{3}$ This was a rather high figure for a country that was then relatively poor. In the 1980s, the tax take settled down to a near-stable 20 per cent. But it began to decline from around 1990, slowly but almost continuously. ${ }^{4}$ By 2014 the figure had almost halved, to just 11 per cent of GDP (see Table 1). This figure is exceptionally low. The government currently collects only about half as much revenue as one would expect when one takes into account the structure of the economy, and the fact that Sri Lanka is now a middle-income country (World Bank 2012: 7). ${ }^{5}$

Table 1 Summary economic and fiscal statistics, 5-year average

\begin{tabular}{|c|c|c|c|c|c|c|}
\hline \multirow[t]{2}{*}{ Period } & \multirow{2}{*}{$\begin{array}{l}\text { Government } \\
\text { revenue as } \\
\% \text { of GDP }\end{array}$} & \multirow{2}{*}{$\begin{array}{l}\text { Ratio of } \\
\text { government } \\
\text { spending to } \\
\text { government } \\
\text { revenue }\end{array}$} & \multirow{2}{*}{$\begin{array}{l}\text { Annual rate } \\
\text { of GDP } \\
\text { growth (\%) }\end{array}$} & \multicolumn{2}{|c|}{$\begin{array}{l}\text { Official development assistance as \% } \\
\text { of government expenditure }\end{array}$} & \multirow{2}{*}{$\begin{array}{l}\text { Terms of } \\
\text { trade (note } \\
\text { 1) }(1951= \\
\text { 100) }\end{array}$} \\
\hline & & & & OECD figures & World Bank figures & \\
\hline & (a) & (b) & (c) & (d) & (e) & (f) \\
\hline 1951-55 & 21 & & & & & 91 \\
\hline $1956-60$ & 23 & & & & & 93 \\
\hline $1961-55$ & 22 & 1.3 & 3.6 & 3 & 3 & 78 \\
\hline $1966-70$ & 21 & 1.3 & 5.3 & 8 & 9 & 60 \\
\hline $1971-75$ & 21 & 1.3 & 2.6 & 7 & 9 & 41 \\
\hline $1976-80$ & 21 & 1.6 & 5.5 & 16 & 23 & 41 \\
\hline 1981-85 & 19 & 1.7 & 5.2 & 19 & 26 & 27 \\
\hline $1986-90$ & 21 & 1.6 & 3.4 & 18 & 27 & 26 \\
\hline $1991-95$ & 20 & 1.5 & 5.4 & 11 & 22 & 25 \\
\hline $1996-2000$ & 18 & 1.4 & 5.0 & 7 & 10 & 23 \\
\hline 2001-05 & 16 & 1.6 & 4.0 & 8 & 12 & 21 \\
\hline $2006-10$ & 15 & 1.5 & 6.4 & 5 & 8 & 20 \\
\hline $2011-14$ & 13 & 1.6 & 7.3 & 3 & 4 & 19 \\
\hline \multicolumn{7}{|c|}{$\begin{array}{l}\text { Sources: Figures in columns (a), (b), (c) and (f) are from the Annual Reports of the Central Bank of Ceylon/Sri Lanka. } \\
\text { Figures in column (d) are from the OECD (<http://www.oecd.org/dac/financing-sustainable-development/development- } \\
\text { finance-data/>), and those in column (e) are from the World Development Indicators (<http://data.worldbank.org/data- } \\
\text { catalog/world-development-indicators }>\text { ). }\end{array}$} \\
\hline
\end{tabular}

Government revenue is conventionally divided into tax and non-tax revenue. The distinction between the two is, however, not clear-cut. In Sri Lanka, as in most countries, non-tax revenue is relatively small: it has accounted for an average of $12 \%$ of total annual revenue since 1970/1. It comprises mainly income from the ownership of property and other assets, and a range of fees and administration charges. In this paper I ignore the distinction, and use the terms 'revenue' and 'tax' interchangeably.

2 e.g. these proposals were in the initial draft communiqué of the Third International Conference on Financing for Development, held in Addis Ababa in July 2015.

3 Unless stated otherwise, all statistics relating to Sri Lanka are those given in the Annual Reports of the Central Bank of Sri Lanka.

$4 \quad$ The raw figures on the tax take provide some scope to disagree on the exact date of the onset of the decline. I have chosen 1990 by calculating a three-year moving average of the tax take.

Within South Asia, Sri Lanka is matched only by Bangladesh as the least effective collector of income taxes. It is only about half as effective as the average low-income country (World Bank 2012). 
This low tax take is a problem, above all for poorer Sri Lankans. ${ }^{6}$ Sri Lanka was once known as a model welfare state. In the 1970s and 1980s, it was widely cited as a model of impressive human development outcomes (health, mortality and education) despite low average income. That is no longer the case. On some calculations, the Sri Lankan government spends less on education than any of its peers in the South Asian region. The quality of public education is poor. A country, which for four decades provided subsidised food grains every week for virtually the entire population - and at one point was spending more than 20 per cent of the government budget on this activity, does not even have a minimally acceptable cash transfer programme to meet the needs of its poorer citizens. These needs are now growing fast because the population is rapidly ageing, and neither the private nor public sectors have the savings that are needed to care for the elderly. Further, the overall pattern of fiscal activities is regressive: wealthier people pay relatively little in tax, but do rather well out of public spending. The Treasury also has a pressing fiscal reason to be concerned. The combination of the low tax take with persistent fiscal deficits and a high public debt burden is now pushing up the cost of government borrowing.

\section{An unprecedented and puzzling decline}

A decrease in the national tax take is not unusual. There are many examples in recent history. ${ }^{7}$ Sometimes, as in the case of a few rich OECD countries over the past two decades, it reflects conscious policy: a determination to 'shrink the state'. More commonly, it reflects governance failures. Internal armed conflict and/or the inability of government to exercise effective authority make it difficult to continue to collect taxes at previous levels. This was, for example, broadly the story in Peru, Rwanda and Uganda in the 1980s and early 1990s. In each of those cases, the emergence of an effective national government restored the tax take to its previous level or more within about a decade.

The decline in the tax take in Sri Lanka over the period since 1990 has a very different character. It was the result neither of sustained explicit policy choices, nor of any particular challenges in physically collecting taxes. It took place gradually over a long time period, rarely received public notice, and occurred in circumstances that would be expected to produce a different result: at least stability in the ratio of revenue to GDP, and perhaps an increase.

In the quarter century after 1990 when the tax take was decreasing, the Sri Lankan economy was expanding rather fast, at an average annual rate of 5.4 per cent (Table 1). There is a strong and well-researched statistical relationship, which holds globally, between the average per capita income of a country and the size of the tax take. The governments of richer countries collect a larger proportion of GDP in public revenue. When national economies grow faster, the tax take tends to increase (Pessino and Fenochietto 2010; Minh Le et al. 2012). Because Sri Lanka was already a relatively high tax economy in the 1950s to the 1980s, a further increase in the tax take was perhaps unlikely. In the absence of any clear policy commitments from successive Sri Lankan governments, we might have expected the tax take to remain at around the long-term average of 20 per cent of GDP. The decline to half that expected figure is a puzzle. It is even more of a puzzle when we take account of the fact that between 1983 and 2009, a period of 26 years, the Sri Lankan armed forces were in almost continuous armed conflict with Tamil separatist groups. ${ }^{8}$ The armed forces expanded

For more details on the issues summarised in this paragraph, see World Bank (2015: 170).

The ICTD Government Revenue Dataset provides the most comprehensive and reliable statistics, covering almost all countries <http://www.ictd.ac/datasets/the-ictd-government-revenue-dataset>.

Tamil separatism was not the only cause of internal armed conflict. During the years 1987-89, much of the country, including Colombo, was affected by a significant insurgency led by the Janatha Vimukthi Peramuna (JVP) - a party of 
greatly in terms of numbers, and purchased much new equipment (Venugopal 2011). It was an expensive war, which might have been expected to put strong pressure on successive governments to raise additional revenue. Governments did not respond in that way. The long-term decline in the tax take began in 1990, only seven years after a low-level separatist insurgency flared up into war in 1983, and at the same time that the number of military personnel was fast expanding. The tax take continued to decline almost every year until the war was concluded. ${ }^{9}$ It is important to note that, just as the war did not prevent the economy from growing steadily, it did not make raising revenue significantly more difficult. The conflict was fought mainly in the peripheral agricultural areas of the North and East of the country that had never been the source of much tax revenue. It did not significantly interfere with tax collection at the points where it is heavily concentrated: the port and airport in Colombo (Sections 2 and 8). Further, the steepest decline in the tax take was in the years after the war ended in $2009 .{ }^{10}$ Internal conflict does not explain the decline in the tax take. The decline was clearly the result of policy choices, even if those choices were rarely articulated consciously and publicly.

In Section 2, I explain why Sri Lanka was a high-tax economy in the years before 1990. Then, in Sections 3 to 8, I attempt to resolve the puzzle of the subsequent decline.

\section{Why was the tax take high in the mid- twentieth century?"}

Between 1950 and 1989, the Sri Lankan government's tax take averaged 21 per cent of GDP. Why was the tax take so high in what was then, in the global context, a low-income country? There are broadly four reasons.

First, the economy has, since the colonial era, been intrinsically taxable. Successive governments had the ability to raise revenue relatively easily through taxing international trade and a relatively wealthy and commercialised economy, without needing to either: (a) develop a very high capacity tax collection apparatus, (b) extract revenue directly - and inevitably somewhat painfully - from small-scale cultivators, ${ }^{12}$ or (c) tax any significant component of the population directly. In the context of the South and South-East Asia region, Sri Lanka was a high-income country during the colonial period. ${ }^{13}$ The reason was the

the majority Sinhalese community. For some months, the JVP succeeded in significantly disrupting economic activity (Moore 1993). However, this left no visible mark on revenue collection levels.

$9 \quad$ The National Security Levy was introduced in 1992, ostensibly to pay for the war. Between 1995 and 2002, when it was abolished, it provided more than $10 \%$ of revenue annually. This did not, however, stem the steady decline in the overall tax take. The Nation Building Tax, which has provided over $4 \%$ of total revenue annually, was introduced in 2009 , the year the war ended. As is explained in the next footnote, the total tax take began to decline particularly steeply immediately after the Nation Building Tax was launched.

10 Total revenue collection averaged $21.0 \%$ of GDP over the period 1989-1991 (Table 1). Over the next 20 years, until the end of the war in 2009 , the tax take declined by 6.4 percentage points - an annual average of 0.32 percentage points. Over the five-year period from 2009 to 2014 , the tax take declined by 3.3 percentage points - an annual average of 0.66 percentage points. This was in large part the direct result of major tax giveaways in the 2010 budget.

11 Snodgrass (1966) is an excellent source of statistics and analysis of the economic history of Sri Lanka.

12 In most of the rest of South Asia, direct taxes on the owners or cultivators of agricultural land, collected on the basis of detailed written records of who owned and cultivated each piece of land, were the dominant source of colonial government revenue in the $19^{\text {th }}$ century, and a significant source in the early part of the $20^{\text {th }}$ century. Land taxes provided an important platform for the Congress Party and other nationalist movements to mobilise popular support against colonial rule. By contrast, Sri Lankan rulers historically had found it easier to extract revenue from international trade than from agriculturalists. Until 1893, the British colonial administration collected a small amount of revenue from taxes on the production of rice and other grains. The grain tax was abolished once the plantation sector became a buoyant source of revenue in the 1880s (Roberts 1973).

13 In 1820, average per capita income in Sri Lanka was about the same as in India. By 1939, it was double Indian levels (Maddison n.d.) In the early $20^{\text {th }}$ century, large numbers of people had moved to Sri Lanka from India for manual work, notably in the plantations and in Colombo. 
dominance of the plantation export economy. The production and export of tea and, to a lesser extent, rubber ${ }^{14}$ generated substantial economic surpluses, large profits for British plantation companies (Snodgrass 1966: 66), high levels of economic inequality, high average income - and good opportunities for governments to raise revenue rather easily. ${ }^{15}$ International trade accounted for a high proportion of GDP, partly because large imports of food grains were required to feed the plantation workforce. And international trade dominantly took the form of highly visible bulk commodities - tea and rubber out, food grains and consumer goods in - routed through Colombo, which in the late colonial era was one of the world's busiest ports. ${ }^{16}$ Historically, there has been no easier way for governments to raise substantial revenue at low cost than to levy trade taxes on visible, standardised bulk commodities moving through ports. In this case, almost all trade moved through a single port, which happened to be located a few hundred metres from the heart of government. ${ }^{17}$ The basic tax collection tasks - identification of the tax base, valuation, assessment and collection of dues - are not organisationally challenging. Import and export volumes can be easily verified. Provided corruption among Customs staff can be kept in check, smuggling and tax evasion can be kept at low levels. And, because they are invisible to most citizens, Customs duties typically generate little political opposition.

Second, while colonial governments relied principally on import taxes - and refrained from tapping the export revenue or substantial profits of the plantation sector companies - they did develop a number of other revenue sources that involved more intensive interactions between state bureaucracies and Sri Lankan society. The major categories of government revenue in 1938/39 were: import duties - 47 per cent; surplus from public sector incomeearning activities (land sales, port, post office, electricity, railway, etc.) - 18 per cent; income taxes - 15 per cent; and excise taxes on liquor and tobacco - 13 per cent (Snodgrass 1966: 385). Imagine the colonial administration as a machine for ensuring the continual flow of plantation exports and profits. To achieve that goal, it had to develop and operate road, port, railway and electricity facilities; control the ever-present threat of tropical diseases; manage extensive movement of labour to and from India; make it possible for land to be sold or leased with secure title; establish effective court and police systems; and keep the social peace. The colonial state was relatively intrusive. It extensively reordered economy and society.$^{18}$ It was, correspondingly, relatively costly. In 1929 , the state collected and spent about 14 per cent of GNP (Snodgrass 1966: 62). ${ }^{19}$

14 There were also substantial coconut plantations, but they mainly served the domestic market. For the years 1940,1950 and 1960 , tea accounted for $68 \%$ of the combined value of plantation crop exports, and rubber for $30 \%$ (Snodgrass 1966).

15 The plantation export economy also generated high levels of volatility in export earnings, and therefore in government revenue. World market prices for tea and rubber were volatile for the same reasons that oil and mineral prices fluctuate today. There is a gap of several years between the decision to invest in increased production capacity and actual production increases. In the short term, an increase in demand can push up prices substantially. But, because producers tend to invest in new production capacity in response, large increases in supply, and thus price falls, can follow within a few years. In the 1950s to the 1970s, in particular, the Sri Lankan economy was highly importconstrained. When tea and rubber prices were low, imports were cut back, and the overall level of economic activity declined. As a consequence, the tax take ranged between $16 \%$ (in 1950) and $27 \%$ (in 1978). It became more stable after 1980, when the economy was fast being diversified away from the plantation export sector.

16 Historically there had been substantial port facilities at Galle and Trincomalee, but from the 1880s Colombo port dominated. It also enjoyed a large transit trade, and in 1939 accounted for 95\% of total shipping tonnage (Dharmasena 1980). Smuggling seems to have been limited to very small-scale trade carried in small boats between India and minor ports on the Jaffna peninsula, like Point Pedro and Velvetturai.

17 The collection of revenue by the Customs Department remains highly concentrated in Colombo, now including the airport. In 2014, the Revenue and Services (Provincial) Directorate, which is responsible for all revenue collection outside Colombo, accounted for $0.3 \%$ of the total revenue collected by the Customs Department (Sri Lanka Customs 2015).

18 Under colonial rule, unofficial (or non-state) customary courts disappeared from Sri Lanka. By contrast, in what is now Bangladesh, India and Pakistan, customary courts dealt with at least half of all court cases in the late colonial period (Lange 2009).

19 In 1937, the colonial government of Ceylon spent four times as much per head of population as the colonial governments of India (Frankema 2010). 
Third, Sri Lanka became an unambiguously high-tax economy after independence in 1948 because governments were then minded to go after a prime potential revenue source that had hitherto been untouchable: earnings from plantation exports, and thus the profits of the largely British-owned plantation sector. The first independent government began immediately to levy substantial taxes on plantation exports, ${ }^{20}$ and to cut heavily into the post-tax profits of the plantation companies (Snodgrass 1966: 114). ${ }^{21}$ That government, like its successors, was dominated by a relatively homogenous Sri Lankan socio-economic elite that itself was relatively heavily-invested in the plantation export economy - and acquiring more of the Island's capital stock as the British began to sell (Roberts 1982). Governments were, however, swayed more by the dynamics of highly competitive electoral politics, with high rates of voter turnout, than by the specific material class interests of the political elite. They were motivated to tax heavily because, for the following combination of reasons, they were under strong electoral pressure to expand public spending:22

- At independence, Sri Lankan society (and economy and polity) were relatively capitalist and, in the language of the time, modern. Plantation production had rather thoroughly reordered social, economic and political relationships in most of the island. A modern bureaucratic state had embedded itself relatively deeply in rural as well as urban areas. Compared to most of South Asia, networks of caste, kin, community and patronclientelism had been much weakened (Moore 2008; Lange 2009; Gerring et al. 2011). Further, the experience of formal employment in large-scale organisations was widespread. A collection of large and relatively class-conscious proletariats - especially in the plantations, railways, ports, road transport and in the government clerical services - had created a lively trade union movement. The trade unions frequently exercised their collective power in labour markets. They also helped nurture a range of leftist political parties. From the 1930s, several more or less allied Marxist movements began to develop into mass parties. They obtained a quarter of all votes cast at the 1947 general election. In Sri Lanka, as elsewhere in Asia at that time, there were widespread expectations and fears of a Marxist revolution. It was not enough for the political establishment to respond by expanding their offerings to voters through patron-client networks: the promise of a government job for this person, or an improved road for that village. They also responded to the more universalistic - and expensive - demands from the political left for free health and education for all the working classes (and the peasantry).

- The electoral demand for free universal health and education services in part reflected the fact that in the 1930s the plantation companies had begun to provide such services to

The mode of taxation varied. In 1968, the government introduced the Foreign Exchange Entitlement Certificate (FEEC) device into its exchange control programme. Exporters were required to surrender all the foreign exchange that they earned to the Central Bank. The Central Bank remunerated them in rupees at a relatively unfavourable rate. If that same exporter was able to get permission to purchase foreign exchange in order to import, she would have to pay significantly more rupees to purchase one dollar than she had been paid for each dollar she earned as an exporter. From a fiscal perspective, this is equivalent to placing a tax on exporters.

21 The requirement that all tea and rubber be sold through public auction, rather than private contract, provided the government with data that could easily be used to calculate export earnings for individual estates and companies. It is an indication of how amenable the tea industry was to central planning that during World War 2 all tea was purchased by the Tea Commissioner on behalf on the British Ministry of Food at prices fixed separately for each tea estate, to take account of variations in quality and the cost of production. To tax the plantation sector - and thus most companies and many wealthy individuals - there was no need to develop a sophisticated capacity to interrogate in detail the accounts of the companies that owned and managed plantations and traded in tea and rubber. Nevertheless, it is likely that the profits from plantation production and export were in practice taxed less heavily than the official records suggest. Many of the transactions between the companies that owned the estates, the managing agencies that operated many of them on contract, the commodity brokers in Colombo and London, shippers, tea wholesalers and retailers in London, and insurers were not 'arm's length'. The sector was characterised by complex cross shareholdings, interlocking directorates, and relatively stable long-term, non-competitive relationships between different organisations. This provided many opportunities for what is today termed tax planning, i.e. using accountants to formally shift profits between enterprises, locations, and functions in order to minimise tax obligations (Government of Ceylon 1974). 
the large population resident on their estates. This provided a model and stimulus for demands that the government provide similar services for the rest of the population. ${ }^{23}$

- The expansion of the plantation economy resulted in high levels of road connectivity, and public infrastructure more generally in most rural areas of Sri Lanka, especially the more densely populated areas where the majority of the population lived. High levels of education, literacy, post office provision, road connectivity and direct interaction with public servants - along with early universal suffrage - generated high levels of awareness of national political issues, and facilitated the political mobilisation of the rural population around national and relatively universalistic - rather than local and particularistic - political issues and parties. By the 1960s, levels of voter turnout in Sri Lanka were among the highest in the world (Jupp 1978: 189).

- During World War 2, it was difficult and expensive to procure the large volumes of rice that had hitherto been imported to feed the plantation labour force. The government instituted a rice ration scheme that involved distributing a weekly quota of rice (or wheat flour) to every family for free (or at a subsidised rate). At the end of the war, with independence in sight, the government decided to continue the scheme. The population quickly became very attached to it. Attempts to end or significantly reduce it generated vociferous political opposition, above all in 1953 when violent protests resulted in a change of government. For the next quarter century, successive governments were locked into financing this major expenditure programme (Section 4).

Fourth, governments were encouraged to increase the tax take to high levels because there was little popular resistance to taxation. Especially after independence, one possible reason was that most of the population ${ }^{24}$ were routinely receiving very substantial resources and services from the government: mass formal education; relatively advanced preventive and curative health services; and, most visibly, the weekly rice ration. Likely more important was the fact that the bulk of the population paid few - or no - direct visible taxes at all. ${ }^{25}$ The main exceptions were among the consumers of liquor and tobacco. ${ }^{26}$ The tax collector rarely intruded on most ordinary people, cultivators, informal business enterprise, most domestic wholesale and retail trade, or owners of urban real estate. ${ }^{27}$

It is impossible to confirm a causal connection between this lack of significant experience of taxation, and the ways in which Sri Lankans learned to think about governance and public policy. It is, however, noticeable that, in the politics surrounding the big expansion of public services and public sector resource redistribution in the 1930s to the 1950s, there is little trace of what one might term 'fiscal contract' ideas: notions of some connection between

23 The back story here is that most resident plantation labourers were recent immigrants from India. The colonial government of India took responsibility for their welfare, and put pressure on Sri Lankan colonial governments to ensure that plantation companies provided health and education for their employees (Wickremeratne 1973).

24 The main exceptions were among the Tamil population of recent Indian origin who provided the bulk of the plantation labour force. Many were stateless from 1948 until 1985.

25 Neither were the wealthy much affected by the wide range of policy initiatives taken between the mid-1950s and the mid-1970s to tax them directly: high marginal rates of personal income tax; a Compulsory Savings Scheme; an annual Wealth Tax; very briefly, a tax on large land holdings, and more than one effort to implement the economist Nicolas Kaldor's suggestion of an Expenditure Tax, to be levied on the difference between the assessed annual income and expenditure of wealthy individuals. Collectively, these taxes generated little revenue, partly at least because the Department of Inland Revenue lacked the administrative tools to actually implement the legislation. e.g. the 1968 Taxation Inquiry Commission pointed out that it was hard to tax capital effectively when the Valuation Department, which should have played a central role in valuing assets and maintaining property registers, was not under the control of the Commissioner of Inland Revenue (Government of Ceylon 1968).

26 But informal production and consumption of liquor was widespread, and Buddhist doctrine and mass Buddhist organisations tended to frown on drink and tobacco. It would, however, have been hard to make a convincing case that the activities of the Excise Department were immoral. The Excise Department was established in 1911 to police and tax the liquor trade. Its functions included licensing retail sales of liquor, collecting excise taxes from licensed distilleries, and suppressing unlicensed production and sales of liquor (and drugs). Its mode of operation was, and remains, to some degree paramilitary, and focused on monitoring flows of physical commodities.

27 In the colonial period, Urban Councils levied a recurrent local property tax along the lines of the British local rates system. As in much of South Asia, the system formally continued after independence, with modifications, but declined to become a minor source of public revenue. 
citizenship as entitlement to public services, and citizenship as an obligation to help finance those services through paying taxes. Popular political discourse has been influenced by a Marxian dichotomy between the state, capitalism (and colonial rule and an inadequately national elite) on one side, and, on the other, the people - frequently defined as the working classes and the peasantry. The discourse easily accommodates strong propositions about the financial obligations of the state to citizens, but has little place for arguments about the financial obligations of citizenship (Moore 1989).

\section{Explaining decreasing revenue collection}

Different observers might disagree on what it means to explain a phenomenon as complicated as the long-term decline in the Sri Lankan tax take in the quarter century after 1990. We can sidestep concerns about social science theory and method by presenting three complementary explanations, rooted in different disciplinary perspectives.

First, from the perspective of the tax specialist the answer seems to lie in the very wide range of deficiencies in both tax policy and tax administration in contemporary Sri Lanka. Revenue collection has declined as a proportion of GNP because governments have failed to adapt to major changes in economic structure by modernising revenue systems. As I explain in more detail in Section 9, contemporary Sri Lankan tax policy and administration is antiquated surprisingly so for a middle-income country with a very high level of international exposure. This is not because of any conservative bias against introducing changes. In the realm of tax policy, in particular, Sri Lankan ministers of finance, like those of most other countries, have tended to be hyperactive. ${ }^{28}$ They fiddle endlessly with the tax code. But effective reforms, especially improvements in tax administration, have been modest when set against the radical changes in economic structure since independence: notably, the very big increase in per capita income; and the shift from a plantation export economy oriented to the United Kingdom, to an economy that is much more diverse in every sense, dominated by services. ${ }^{29}$

Anyone with a nose for political analysis might object that this notion of an antiquated revenue system is not so much an explanation for the decline in the tax take, as a more complex way of restating the issue: the tax take declined because governments (deliberately) failed to reform the revenue system to keep up with changes in taxation practices, business models and patterns of economic activity. The second explanation for the decline in the tax take is, therefore, a simple political proposition: governments wanted and willed it, and needed to do little to achieve it except keep quiet and avoid significantly improving the capacity of their revenue collection system. This argument contains a great deal of truth. Without it, we would be in danger of missing some very important points:

- The decline in the tax take has gone hand in hand with major reductions in the types of public spending that mainly benefit poorer people.

- Because of this, and the failure of the revenue system to significantly tax fast-growing incomes and new wealth, the fiscal system has moved strongly against the poor.

- The near-silence about revenue issues in policy discourse over many decades has been in the interests of the wealthier sections of the population.

The argument that it is 'all political' is broadly correct. In that simple form, it is insufficiently nuanced and detailed, and ultimately not very persuasive. The third explanation, which

\footnotetext{
28 e.g. the 1968 Taxation Enquiry Commission produced a list of twenty-one new taxes that had been imposed since 1953/4; only six of them were still in force in 1968 (Government of Ceylon 1968).

29 In 2014 the service sector accounted for $56 \%$ of GDP, the industrial sector $27 \%$, and agriculture, forestry and fishing $8 \%$.
} 
occupies most of this paper, is that there are a range of identifiable political and organisational processes that have particularly contributed to the relative lack of interest of successive governments in maintaining the tax take. I have identified five such processes. For the sake of brevity I will label them 'explanations', but that is somewhat misleading. They interact with one another in complex ways. To some extent, this is a story of path dependence. These five explanations are treated in the following order:

- Declining electoral pressure for large-scale public welfare spending: from the 1940s until the 1970s, the Sri Lankan electorate put strong pressure on successive governments to establish and maintain large-scale public welfare spending - and therefore to raise the revenue to fund it (Section 2). Changes in the character of electoral politics, which became particularly apparent in the 1970s, alleviated that pressure, permitted governments to relate to the electorate in a more clientelistic fashion, and thus made a declining tax take politically more manageable.

- Easy non-tax funding: aid inflows expanded rapidly after the 1977 general election. These provided substitute financial resources, and enabled governments to run larger fiscal deficits without feeling strong pressure to find substitute revenue.

- Institutionalised pressure for tax exemptions: the Greater Colombo Economic Commission (GCEC) was established in 1978 to encourage foreign investment, with a chief executive responsible directly to the executive president. The powers of the GCEC - which was later renamed the Board of Investment - included the right to grant tax exemptions to investors. These powers were steadily expanded and used liberally. This helped to create a broader culture of tax exemptions.

- Absentee finance ministers: for most of the period since 1989, the Ministry of Finance has not been directly managed by a powerful finance minister. The 'revenue interest' within the government apparatus has lacked an effective institutional voice.

- Lock-in to import taxes: import duties have long been a major source of public revenue because they are so easy to collect (Section 2). This dependence has been exacerbated because the Customs Department, which was historically inferior to the Department of Inland Revenue in terms of organisational prestige and competence, has in practice gradually overtaken it, and exercises a correspondingly greater influence on public policy.

To some extent, the ordering of these five explanations is chronological. Note also that the first four explanations are, albeit in varying degrees, rooted in the major transition point in the politics of independent Sri Lanka: the electoral landslide in favour of the United National Party (UNP) at the 1977 general election, and the big changes in political institutions and public policy that were introduced in the next few years. This democratic change to a government promising economic liberalisation - which also marked the end of the established Marxist political parties as an electoral force - brought about a major increase in aid inflows, and much greater involvement of international organisations in shaping economic policy. In summary, the major longer-term consequences were:

- A broad shift in economic policy in favour of private investors and capitalism, and against large-scale welfare spending - especially spending on universalistic programmes rather than political patronage.

- A big increase in public investment and a permanent shift from economic stagnation to steady economic growth - much aided later by the acceleration of economic growth in nearby India.

- The establishment of a more exclusionary - and sometimes authoritarian - political system involving, in particular: the concentration of power in the political executive (and mostly in the hands of the political elite); and the 'taming' of mass political organisations through varying combinations of repression and organised patronage.

- The institutionalisation of the interests of private investors within the government machinery. 
The five explanations listed above are explored in Sections 4 to 8 respectively.

Table 2 Sources of government revenue (\%), 1970/1-2015, 5-year average

\begin{tabular}{|c|c|c|c|c|c|c|c|c|c|}
\hline 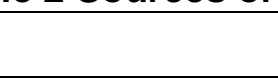 & $\begin{array}{l}1970 / 1 \\
-1975\end{array}$ & $\begin{array}{l}1976- \\
1980\end{array}$ & $\begin{array}{l}1981- \\
1985\end{array}$ & $\begin{array}{l}1986- \\
1990\end{array}$ & $\begin{array}{l}1991- \\
1995\end{array}$ & 2000 & $\begin{array}{l}2001- \\
2005\end{array}$ & $2006-$ & $\begin{array}{l}2011- \\
2015\end{array}$ \\
\hline $\begin{array}{l}1.1 \text { Taxes on } \\
\text { foreign trade }\end{array}$ & 38 & 42 & 35 & 30 & 18 & 15 & 14 & 17 & 17 \\
\hline Exports & 11 & 23 & 17 & 4 & 0 & 0 & 0 & 0 & 0 \\
\hline $\begin{array}{l}\text { Imports (net) (Note } \\
\text { 1) }\end{array}$ & 8 & 13 & 19 & 26 & 18 & 15 & 12 & 10 & 8 \\
\hline Levies (Note 2) & 0 & 0 & 0 & 0 & 0 & 0 & 2 & 7 & 9 \\
\hline $\begin{array}{l}\text { Receipts from } \\
\text { FEECs (net) (Note 3) }\end{array}$ & 19 & 6 & 0 & 0 & 0 & 0 & 0 & 0 & 0 \\
\hline $\begin{array}{l}1.2 \text { Taxes on } \\
\text { domestic goods } \\
\text { and services }\end{array}$ & 29 & 37 & 36 & 39 & 52 & 53 & 57 & 47 & 46 \\
\hline Turnover tax & 14 & 10 & 25 & 28 & 27 & 12 & 0 & 0 & 0 \\
\hline GST/VAT - Domestic & 0 & 0 & 0 & 0 & 0 & 6 & 16 & 15 & 11 \\
\hline GST/VAT - Imports & 0 & 0 & 0 & 0 & 0 & 5 & 15 & 15 & 10 \\
\hline $\begin{array}{l}\text { Excise taxes (liquor, } \\
\text { tobacco, petroleum, } \\
\text { vehicles and others) }\end{array}$ & 14 & 26 & 10 & 11 & 14 & 17 & 20 & 16 & 24 \\
\hline $\begin{array}{l}\text { National Security } \\
\text { Levy (Note 4) }\end{array}$ & 0 & 0 & 0 & 0 & 11 & 13 & 6 & 0 & 0 \\
\hline Licence fees & 2 & 1 & 1 & 1 & 0 & 1 & 0 & 0 & 1 \\
\hline $\begin{array}{l}1.3 \text { Taxes on net } \\
\text { income and profits }\end{array}$ & 16 & 12 & 16 & 12 & 13 & 13 & 14 & 18 & 17 \\
\hline $\begin{array}{l}\text { (Of which, corporate } \\
\text { income tax) }\end{array}$ & na & 13 & 11 & 8 & 7 & 6 & 6 & 9 & 9 \\
\hline $\begin{array}{l}\text { (Of which, non- } \\
\text { corporate income } \\
\text { tax) }\end{array}$ & na & 3 & 4 & 4 & 5 & 4 & 4 & 4 & 2 \\
\hline $\begin{array}{l}\text { Combined corporate } \\
\text { and non-corporate } \\
\text { income tax }\end{array}$ & 16 & 12 & 16 & 12 & 13 & 13 & 10 & 13 & 12 \\
\hline $\begin{array}{l}\text { Save the Nation } \\
\text { contributions }\end{array}$ & 0 & 0 & 0 & 0 & 0 & 0 & 0 & 0 & 0 \\
\hline Tax on interest & 0 & 0 & 0 & 0 & 0 & 0 & 4 & 5 & 5 \\
\hline $\begin{array}{l}1.4 \text { Stamp } \\
\text { Duty/Cess } \\
\text { Duty/Social } \\
\text { Responsibility } \\
\text { Levy, etc. (Note 5) }\end{array}$ & 0 & 0 & 0 & 0 & 0 & 4 & 1 & 6 & 9 \\
\hline 1.5 Bank debit tax & 1 & 0 & 0 & 0 & 0 & 0 & 1 & 1 & 0 \\
\hline $\begin{array}{l}1.6 \text { Taxes on } \\
\text { property (Note 6) }\end{array}$ & 1 & 1 & 2 & 4 & 4 & 2 & 0 & 0 & 0 \\
\hline $\begin{array}{l}1.7 \text { Taxes on } \\
\text { Treasury Bills }\end{array}$ & 0 & 0 & 0 & 2 & 1 & 0 & 0 & 0 & 0 \\
\hline Total tax revenue & 85 & 93 & 88 & 86 & 87 & 87 & 87 & 89 & 89 \\
\hline Non-tax revenue & 15 & 7 & 12 & 14 & 13 & 13 & 13 & 11 & 11 \\
\hline Total revenue & 100 & 100 & 100 & 100 & 100 & 100 & 100 & 100 & 100 \\
\hline
\end{tabular}

Source: Annual Reports of the Central Bank of Sri Lanka.

Note 1: These figures refer only to import duties, narrowly defined, and not to the much wider range of taxes levied on imports (see main text).

Note 2: Levies = a changing combination of Ports and Airports Development Levy, Regional Infrastructure

Development Levy, the Specific Commodity Levy, and others.

Note 3: This refers to the revenue earned from maintaining a dual foreign exchange rate. FEECs $=$ Foreign

Exchange Entitlement Certificates.

Note 4: The National Security Levy was introduced in 1995, explicitly to finance the war against separatism. It was a

levy on the value of imported and manufactured commodities, at variable rates, and with exemptions.

Note 5: Includes: Stamp Duty on a diverse range of financial and legal transactions; import and export cess duties on a range of commodities; the Social Responsibility Levy, which was a surcharge on income taxes, excise duties and customs duties; the Nation Building Tax, charged on a range of import and export commodities.

Note 6: Includes taxes on property transfers and taxes on capital transfers (Estate Duty, Wealth Tax, Gift Tax, etc).

After 2000 , these taxes are incorporated into 1.4 


\section{Changing electoral pressures}

In the 1940 s to 1970 s, Sri Lankan governments were committed to large-scale spending on social welfare for two broad reasons explained in Section 2: a strong popular political movement, organised in trade unions and Marxist parties and mobilised around universalistic programmatic demands; and a lock-in to a large food subsidy programme (rice ration) that had originally emerged to cope with food scarcity during World War Two. Both of these underpinnings of large-scale welfare spending - and thus of the incentives to maintain a high tax take - were eroded: the first gradually, but with a step change in the late 1970s, and the second rather quickly, again in the late 1970s. One of the more visible correlates was the emergence of a more clientelistic pattern of politics, with lower rates of political participation, less stable political party affiliations on the part of both politicians and voters, and the more discretionary, politicised allocation of public resources to small groups of voters. These changes were in turn interrelated with two other major features of national politics:

increasingly authoritarian and repressive governance (until early 2015), and ethnic conflict. Some major elements of this long and complex story are as follows:

- The socio-economic basis for the prominent socio-political role of the proletarian trade unions and Marxist parties began to decline from a peak in the 1940s and 1950s. The near-stagnant plantation economy was failing to generate new proletarian jobs. By contrast, there was a relative expansion in the small-scale agriculture sector, principally because: (a) smallholders, supported by the distribution of large areas of state land in small parcels, moved into the production of tea (and to some extent rubber) in a significant way; and (b) after the introduction of responsible democratic internal selfgovernment in 1931, governments began to invest in the large-scale resettlement of (mainly Sinhalese) rural families as rice producers in irrigation colonies in the sparsely populated Dry Zone in the North and East of the island. ${ }^{30}$

- Trade unions became less solidaristic as political parties established competing trade union organisations and, especially in the growing proportion of the formal sector that was in public ownership, unions became more strongly enmeshed in patronage networks (Kearney 1971).

- Malaria, which had hitherto been endemic, was to a large degree eradicated in the later 1940s. This resulted in a rapid increase in the birth rate, and, within two decades, the appearance of a 'youth bulge'. These young people were mainly literate, and many were educated to secondary level and beyond. But their education was of poor quality and limited relevance to the labour market. Worse, the economy was generating few new jobs. For three decades or more after the late 1960s, there was a large reservoir of educated unemployed youth mobilisable for political purposes. Many were mobilised into radical insurrectionary identity-based political movements. ${ }^{31}$ This exacerbated the tendency for ethnic politics to dominate the political agenda at the expense of the class politics that had previously been so prominent.

- The prominence of Marxist ministers in the 1970-1977 coalition government helped disguise the decline in the electoral base of the Marxist parties. They gained no seats in the 1977 parliamentary election, and thereafter were only sporadically represented in the legislature through a nomination process to the National List.

- The new UNP government elected in 1977 was motivated and buoyed up by: a two-thirds majority in the legislature; a tough-minded, politically-astute leader; disillusion after several decades with statist and socialist economic policies that seemed to have failed to

30 Rapid population growth, in large part induced by the near-eradication of malaria in the late 1940s, underpinned these changes in the pattern of agricultural production.

31 I refer to the first two incarnations of the (mainly Sinhalese) JVP, which engaged in insurrections in 1971 and 1988/89 respectively; and to a range of Tamil separatist organisations, principally the Liberation Tigers of Tamil Eelam (LTTE), which also have their origins in the 1970 s. 
find sources of economic growth to replace the declining plantation export sector, ${ }^{32}$ aid donors keen to support a new democratic government that was giving them the messages they wanted to hear about the virtues of the market economy and economic liberalisation; and a private sector that was discovering new and more diverse types of profitable enterprise - notably in export garment manufacture in free trade zone conditions, hotels, tourism, finance and real estate.

- The new government took an authoritarian turn. A new constitution promulgated in 1978 created an executive presidency with wide powers, and in various respects exacerbated the trend towards unconstrained executive rule that had been initiated in another new constitution introduced by the previous government in 1972. The UNP government adopted a robust policy towards (opposition) trade unions and political parties, and in various ways interfered in and further weakened the main opposition party, the Sri Lanka Freedom Party (SLFP). Rather than face new parliamentary elections in 1982, the government organised a referendum to extend the life of the existing parliament. An unprecedented degree of repression and intimidation was employed to win this referendum (Manor 1984).

- This new government, with the strong support of the World Bank, seized the political opportunity to put an end to the rice ration scheme - under the guise of reforming it to make it more fit for purpose. The scheme had taken the form of a universal per capita weekly entitlement to a defined quantity of food grains - at different times free or at a subsidised price. Under the replacement system introduced in 1979, about half of households were allocated vouchers (food stamps) that could be used to purchase a range of basic consumer goods. The food stamp system was designed to self-destruct politically. The value of the stamps was fixed in cash terms at a time of high inflation, and thus declined steadily in real terms. There was no mechanism for admitting new recipients once the original determination of household eligibility was made in 1978. And that determination was made in such a cursory manner, with wide scope for local political and administrative discretion, that the new system was discredited from the beginning. Most people did not believe that food stamps were targeted towards the most needy households. ${ }^{33}$

- Once the rice ration scheme had been eviscerated in this way, there was very little political resistance to further steps to cut the budgetary costs, further politicise decisions about who would benefit, and introduce procedural complexities that both necessitated/validated the use of micro-level administrative discretion and further discouraged political mobilisation in the interests of actual or potential beneficiaries. A universalistic programme became highly discretionary and clientelistic. The rice ration scheme had near-universal coverage (in reality, as well as nominally), and accounted for a substantial proportion of public spending. The food stamp scheme initially covered about 50 per cent of the population. In 1994, it was replaced by the Samurdhi (prosperity) scheme, which involved a complex mixture of cash transfers, loans, obligatory savings, training, dedicated banks and local infrastructure spending, all administered by a highly politicised cadre of Samurdhi officers. Beneficiaries accounted for around 30 per cent of the population. In 2012, that was replaced by the even more complex and diffuse Diva

32 This perception was exacerbated by the coincidence in the period 1970-1977 of (a) the most statist government with (b) a particularly steep decline in Sri Lanka's terms of trade. Foreign exchange and imports were unusually scarce. Notions of socialism and economic planning were deeply discredited.

33 The way in which the minister of finance announced the reform in his 1978 Budget Speech illustrates the extent to which this was an executive decision. The minister did not feel obliged to provide any details of the mechanisms to be used to determine which households would be eligible for food stamps. 'It is now proposed to reduce substantially the distribution of rice at subsidised prices by withdrawing the rice ration from that part of the population deemed to have incomes above the minimum level. The administrative procedures for determining this minimum level and for affecting the withdrawal are already in place and will be put into effect in the next two or three weeks and I need not detain this House with the detail' (Republic of Sri Lanka 1977). He then misled parliament by implying the intention to continue to provide a food entitlement defined in terms of weekly quantities of rice and wheat flour, despite the arrangements already in place to shift to food stamps denominated in terms of financial value (ibid). 
Neguma scheme, which covered perhaps 20 per cent of the population. By this point the programme was very low cost (World Bank 2015: Chapter 3).

- This combination of increasingly clientelistic politics, growing ethnic conflict (with near continuous armed conflict with Tamil separatist groups between 1983 and 2009, and a major Sinhalese youth insurgency in other areas of the country in 1987-89), increasingly repressive government (until early 2015), the large expansion of the armed forces, and the wider availability and use of unlicensed firearms, decreased the benefits and increased the risks attached to political and civil society activism. Rates of electoral participation peaked in the 1977 general election and 1982 presidential election.

- The weakening of the interest groups that had supported universalistic social spending programmes is clearly reflected in the erosion of those programmes. The fate of the rice ration scheme has been summarised above. The other very marked change has been a substantial decline in the proportion of public spending - and an even larger decline in the proportion of GDP - that is devoted to education. The Sri Lankan government currently spends less of its budget on education than any other government in the South Asian region (World Bank 2011). ${ }^{34}$

Open democratic politics, a mobilised and (somewhat) class-conscious electorate, and largescale public spending on universalistic social welfare programmes had been mutuallyreinforcing phenomena. Subsequently, the weakening of any one of these institutions contributed to the weakening of the others. In an increasingly repressive and clientelistic political system, governments could more efficiently purchase the support they needed to remain in power by: (a) buying over Members of Parliament (MPs) and other effective political organisers - hence the increasing frequency with which these people changed allegiances and parties, and (b) distributing public resources on a discretionary basis to small groups, as through the Samurdhi and Diva Neguma anti-poverty programmes (above). ${ }^{35}$ Less pressure to spend meant less pressure to protect the level of the tax take.

\section{5 'Easy' non-tax funding}

The electoral pressures to fund large-scale social spending programmes abated slowly and over the long term. Other causes of the long-term decline in the tax take kicked in more quickly. This was especially true of the shift in the ways of funding government spending that occurred in the late 1970s: a move from primary reliance on revenue raised by government to a greater dependence on what I label easy non-tax funding - combinations of (a) aid, (b) deficit financing, and, later, (c) commercial borrowing.

There was a latent revenue crisis in the late 1970 s and early 1980 s. Since independence governments had been heavily taxing the plantation economy. The high tax regime depended in large part on heavy taxation of plantation exports (Section 2). That was possible as long as the plantation companies earned significant surpluses. Profits had been high in the colonial era and beyond, but in the long term the taxable surplus was disappearing. As was the case with so many primary commodities, the world market prices for plantation products were, behind all the short-term fluctuations, steadily declining relative to the prices of the manufactures and other products that Sri Lanka imported. ${ }^{36}$ Further, the British

\footnotetext{
$34 \quad$ This low spend is reflected in the poor quality of the education system and the systematic mismatch between what is taught in schools and universities, and the aptitudes and skills required in labour markets. This is widely recognised as a key constraint on increasing economic productivity. The performance of the health care system has not deteriorated in the same way, because of large-scale private health spending.

35 There is still one significant exception to this pattern: farmers continue to receive a substantial fertiliser subsidy that constitutes an important item of public spending, and to some extent they are still organised and mobilised to strongly resist attempts to reduce the subsidy. This happened most recently in early 2016.

36 The ratio of the average price of a country's exports to the average price of its imports is known as the terms of trade. It is expressed as an index. Taking the 1938 figure as 100, by the period 1980-89 Sri Lanka's terms of trade had
} 
plantation companies, alarmed by the frequent talk of nationalisation, had long been running down their estates in Sri Lanka, and shifting their assets and efforts to new tea enterprises in East Africa. When the Sri Lankan government finally nationalised privately-owned estates in 1972 and company-owned estates in 1975, they acquired rather degraded resources. The politicisation of the management of the new public sector estate companies made the situation worse. The large increase in global tea prices in 1976-79 marked the last big opportunity for the government to fill its purse from taxing plantation exports. During the period 1970/1-1982, revenue from taxes on exports was on average three times as large as revenue from import taxes. ${ }^{37}$ After 1982 world tea and rubber prices remained low, and export tax revenue quickly shrank to nothing. Between 1970/1 and 1982 export taxes on average accounted for 28 per cent of government revenue. Four years later they accounted for only 4 per cent. ${ }^{38}$

The government responded actively to this loss of a key revenue source. The Business Turnover Tax (BTT), which had previously applied only to domestic manufactured products, was extended to imported manufactured goods in 1981. The contribution of BTT to total revenue increased from 13 per cent in 1980 to 27 per cent in 1983. The additional revenue from BTT did not, however, cover more than about half the revenue lost from the disappearance of export taxes. There was no complementary effort to raise more revenue from direct taxes on income and profits - and even less on wealth. In the 1980s (corporate and personal) income taxes continued to account for the same 14-15 per cent of total revenue as in the 1970s, and indeed in 1938/9 (Section 2) - and, therefore, for a declining proportion of what was now a fast-growing national economy.

Why was the policy response to the loss of export tax revenue not more vigorous? At first sight the answer seems obvious: from 1977 the Sri Lankan government suddenly became a large aid recipient. Having accounted for only 9 per cent of government spending in the period 1973-1977, aid covered 19 per cent over the next five years. Several factors explain the increase: the growth in global aid budgets; the landslide election in August 1977 of a government that rejected notions of socialism and central planning, and embraced newlyfashionable ideas of economic liberalisation; and the willingness of that government to cooperate with aid donors, notably (a) in major public investments in the much-accelerated Mahaweli programme of large-scale hydropower, irrigation and land settlement projects, and (b) in putting an end to the subsidised rice ration scheme (Section 4).

The generous aid available after 1977 reduced pressure on the government to find more complete substitutes for disappearing export tax revenue. That is true, but it is not the full story about the shift to easy funding. In 1978 the routine level of fiscal irresponsibility - the size of the fiscal deficit that governments regarded as normal or acceptable - ratcheted up, suddenly, substantially and permanently. In 1977 total government spending (minus debt repayments) amounted to 132 per cent of total government revenue. The deficit had been relatively stable at that level since 1958. In 1978 it jumped to 151 per cent. Thereafter it rarely and only briefly fell much below that figure. Between 1978 and 2014, it averaged 157 per cent. In other words, until 1977 the fiscal deficit averaged just under a third of government revenue collection; after 1977 it averaged just over half. And it remained there

deteriorated to 20. To put it another way, in the 1980s the economy had to generate five times as much exports as it had done in 1938 to pay for the same level of imports. The terms of trade have deteriorated further since 1989, but not so precipitously as earlier.

37 This figure $-298 \%$ - assumes that all revenue earned by government through the monopolistic control of foreign exchange through the Foreign Exchange Entitlement Certificate scheme is to be accounted as taxes on exports. This involves some exaggeration of the role of export taxes. It is not possible to calculate a more precise figure.

38 The last year for which export tax revenue is recorded in the standard revenue accounts was 1993. The abolition of export taxes helped motivate private investors to buy the long-term leases of nationalised plantations that the government offered them in 1992. 
even after aid levels began to decline (Table 1). ${ }^{39}$ This is a story not just of aid (with a large grant element), but of easy financing more generally.

Until 1977 governments routinely spent more than they collected in taxes. But overspending was limited by the low levels of financing through aid inflows, and fear of triggering hyperinflation. No commercial lender would lend significant amounts of money to a government that was presiding over a relatively stagnant economy, built largely around a plantation export sector that had poor long-term prospects. After 1977 the constraints on deficit spending were reduced. Aid inflows increased. Concessional aid eventually declined, especially once Sri Lanka reached the status of a middle-income country. But, in the last decade in particular, lending on near-commercial terms for infrastructure development especially ports, airports and roads - has been provided on a large scale from China. That, in turn, reflects recent changes in Sri Lanka's relationships with, and significance to, the rest of the world. From a geopolitical perspective, the expansion of China's naval presence and ambitions in the Indian Ocean means that Sri Lanka's port facilities have regained the strategic importance they held in the context of European imperialism in the eighteenth, nineteenth and early twentieth centuries. More importantly perhaps, the rapid growth of the Indian economy over the past two decades - allied to the expansion of global trade (until recently) - has made Sri Lanka a major trans-shipment centre. ${ }^{40}$ Port and airport facilities have expanded rapidly. Colombo is unlikely to fully regain its nineteenth and early twentieth century ranking as one of the world's major ports, but, after more than half a century in the doldrums, it is moving up the global rankings for shipping volumes.

From a global perspective, Sri Lanka is again, as it was when the tea plantation economy began to expand fast in the 1880s, a piece of valuable real estate from both a geopolitical and economic perspective. ${ }^{41}$ Consequently, the scope for government to borrow on more or less commercial terms has expanded considerably. Much as aid donors or commercial lenders might enjoin the government to reduce the size of the fiscal deficit, they are in aggregate willing to lend so much that fiscal prudence is unnecessary. The incentives to raise the tax take to reduce the fiscal deficit have been much muted since this shift to easy funding after 1977.

\section{Institutionalised pressure for tax exemptions}

Tax exemptions in their contemporary form were introduced in Sri Lanka in 1951, and slowly expanded. They were under the control of the Ministry of Finance. From the perspective of orthodox tax economists, there were already too many of them in 1977 (Jenkins 1988: 5). Not only were they used much more widely after the change of government in 1977 (Waidyasekera 2012: 45-6), but an almost unrestricted and largely arbitrary authority to grant them was embedded within the apparatus of government. Boosting private investment was a policy priority for the government elected in 1977. Partly because of continuing nationalist sentiments, the new government initially declared that foreign investment would be confined to a new Export Processing Zone (free trade zone) that was to be established north of Colombo, with the purpose of boosting exports of products other than the traditional tea, rubber and other agricultural commodities. The Export Processing Zone (EPZ) was a success. Within a few years Sri Lanka became a major exporter of garments, especially to

\footnotetext{
39 The contribution of aid to government spending peaked in the early 1980 s (20\% in 1981-83). Thereafter it declined steadily, except for a brief spike in response to the 2004 tsunami. It currently stands at $2 \%$ (Table 1).

It was estimated in 2013 that, because of limited facilities at India's ports, about one-sixth of all containers bound for India were trans-shipped through Colombo (The Economist, 10 August 2013: 52).

Trincomalee has a superb natural harbour, and was a significant naval base under colonial rule. Rumours about the ambitions of the American, Chinese or Indian navies in relation to Trincomalee are routine.
} 
the United States. The organisational arrangements surrounding the EPZ were, however, to have considerable - and largely negative - longer-term consequences for raising revenue.

In 1978 the government created the Greater Colombo Economic Commission, with a general mission to boost foreign investment, and a specific mandate to establish and manage free trade zones. The GCEC was an independent body responsible directly to the president. The first chairman and director general was Upali Wijewardena, Sri Lanka's most successful and flamboyant entrepreneur, and a close relative of the president. In practice, Wijewardena had almost total autonomy to run the GCEC. There were few limits on his power to grant tax holidays for new investments. The authority of the GCEC gradually expanded. In 1982 it took over the powers of the Department of Customs in relation to the EPZs. Its authority to promote export-oriented industry was expanded beyond the territorial limits of the free trade zones to cover the whole country. In the early 1990s the GCEC was renamed the Board of Investment, and given the authority to offer tax incentives - tax holidays, concessionary corporate income tax rates, generous depreciation allowances, and import and excise duty exemptions - to all investors, and not just those producing for export. It was at this point that the number of projects with tax holidays from the Board of Investment began to grow rapidly. There were only a few dozen in the late 1980s. The figure peaked at over 600 in 2008 (World Bank 2012: 36).

The Ministry of Finance also had authority to offer tax incentives under the Inland Revenue Act. 'Although originally these incentives were focused on areas not covered by the Board of Investment Act, there has been significant overlap in recent years' (World Bank 2012: 36-7). On 27 April 2016, the government announced that in future only the Ministry of Finance would have the power to grant tax incentives. This comes after a period of about 35 years during which larger investors - most of whom are local rather than foreign - became increasingly accustomed to lobbying for and expecting tax exemptions. ${ }^{42}$ Yet levels of private investment have never been particularly high. In practice, arguments about the need to motivate investors with tax exemptions have been used to justify a very indulgent position towards the taxation of corporate profits.

\section{Absentee finance ministers}

From 1948 to 1978, Sri Lanka was governed under the Westminster model: prime minister and Cabinet were ultimately responsible to parliament. Under that regime, ministers of finance were almost universally very senior politicians, typically at the forefront of policy debates. In 1978, the newly-elected government introduced what is often termed a 'Gaullist' constitution, which combined a prime minister and Cabinet drawn from elected legislators with a powerful, directly-elected executive president. The first executive president, J. R. Jayawardena, held office until January 1988. Although his government was increasingly authoritarian in its dealings with other political parties and opposition in the trade unions and civil society (Section 4), Jayawardena was in control of his party and ruled in a relatively collegial fashion, giving considerable autonomy to a number of senior lieutenants. ${ }^{43}$ Among them was Ronnie de Mel, arguably the most influential minister of finance in Sri Lanka's history, who held the post continuously from July 1977 until January 1988.

\footnotetext{
42 There is no single authoritative list of tax exemptions. In March 2016, S. R. I. Perera of KPMG, Colombo stated that there were more than 140 exemptions for VAT alone (Daily Financial Times, 23 March 2016). The following were among the activities that received new tax incentives in the 2012 budget: the import of high quality pharmaceutical products; health services; research (income and VAT); the personal income tax of people engaged in research and technology; all income from the management of sports facilities; the income of international sports trainers; and fitness equipment for use in sports complexes (customs duties and VAT).

43 A number of these figures, including the people who ran the GCEC (Section 6), the large Mahaweli irrigation and hydropower investment programme, the national airline and the Ministry of Policy Planning and Plan Implementation, were not elected politicians.
} 
The next executive president, $R$. Premadasa, had a strong popular electoral base but for a range of reasons, including his social origins, was something of an outsider to the national political elite. He marginalised senior party colleagues, and ruled in an autocratic fashion. During his first year in office he appointed an independent minister of finance, and left in place the existing secretary to the ministry, a distinguished career public servant. After a year, in April 1989, radically different arrangements were introduced. They were more aligned to the reality of a quasi-autocratic executive presidency. The figurehead prime minister, who formally held several other portfolios, nominally became the minister of finance. Real power lay with the new secretary, R. Paskaralingam, a civil servant with almost no public profile but powerful personal networks within the public service, and a reputation for getting things done. Paskaralingam became the dominant channel through which the president ruled the country. The notion that the two of them together controlled the government became almost universally accepted. ${ }^{44}$ Paskaralingam was secretary to the Ministry of Finance for five years. He remained in post for almost a year after President Premadasa was assassinated, when the former figurehead prime minister, D. B. Wijetunge, became caretaker president.

With small variations and brief exceptions, this combination - a nominal minister of finance and a powerful secretary of finance with wide-ranging powers responsible directly to the president - was in place from 1989 until early 2015:

- Except for a brief period of two and a half years in 2001-4, when President Chandrika Kumaratunga had to accept a government formed by the political opposition, the minister of finance portfolio was held either by the president (November 1994 to December 2001, and November 2005 to January 2015) or by a politician with little independent standing (April 2004 to November 2005).

- With a few limited exceptions, the post of secretary to the Ministry of Finance was held by people known to be trusted by the president and entrusted with wide decision-making powers, including in relationship to investors and aid donors. The most prominent was $P$. B. Jayasundera, who held the post for a total of almost 13 years, under President Kumaratunga and her successor Mahinda Rajapaksa. ${ }^{45}$

What reason do we have to believe that these organisational arrangements, which I label 'absentee finance ministers', contributed to the decline in the tax take? Consider the likely role of ministers of finance in two sets of economic and geostrategic circumstances:

- In the first scenario, which corresponds to Sri Lanka before 1977, the government faces sluggish economic growth in the long term, limited aid inflows and the near-absence of external commercial financing. No external power is willing to prop it up financially for geostrategic reasons. In these circumstances, any government determined to avoid hyperinflation needs, in addition to organisational and technical competence in the Ministry of Finance and the Central Bank, a minister of finance with real political influence: someone who can control the spending urges of other ministers and obtain political support for revenue collection measures.

- In the second scenario: aid inflows increase; the rate of economic growth accelerates, both because the country is an important link in global shipping chains at a time when global commodity trade is growing fast, and because a very large neighbouring economy is expanding rapidly; an emerging superpower has a strong interest in its excellent port

$44 \quad$ This was not true in respect of very pressing security issues, which were handled by other trusted lieutenants. When Premadasa became president, parts of the North of the country were controlled by the Indian armed forces, who were at that point battling with Tamil separatists; and armed leftist-nationalist insurgents had a major influence in large parts of the rest of the island.

45 In 2008 T. B. Jayasundera was removed from office by the Supreme Court because of violation of tender procedures relating to a very large contract for the expansion of the Port of Colombo. In the following year, a new Chief Justice over-ruled that decision, and Jayasundera returned to his post. 
facilities, and is willing to finance a great deal of infrastructure development; and commercial lenders are willing to risk their money by making loans to a government that has so many friends. This is a simplified characterisation of Sri Lanka since 1977. A strong minister of finance is less essential because controlling spending and raising revenue are lower political priorities. The most ambitious and able ministers might be more interested in heading spending ministries, from where they can nourish their own political networks and constituencies without incurring the unpopularity that typically accrues to ministers of finance. More important, presidents have more leeway to use control over the Ministry of Finance - typically a strategic point from which to monitor and control the apparatus of government generally - for their own political purposes. They might be especially inclined to use it for control purposes if they do not feel that their own political party or faction is a reliable, loyal and effective instrument of rule.

What is the evidence that the absence of a powerful minister of finance - interacting with other factors, especially easy non-tax funding (Section 5) - has contributed to the decline in the tax take? First, there is the deductive argument set out above. Second, people familiar with economic policymaking in Sri Lanka over the long term find the argument convincing. Third, the timing fits:

- The absentee finance minister arrangement was introduced in April 1989; the steady decline in the tax take dates from 1990.

- There was a brief interruption for 29 months between December 2001 and April 2004, when the UNP enjoyed a parliamentary majority and Ranil Wickremesinghe became prime minister - although the president, Chandrika Kumaratunga, who was from the SLFP, was not cooperative. The minister of finance, K. N. Choksy, was a senior member of the UNP. That government enjoyed neither the longevity nor the power to effect much fiscal reform, but did attempt one ambitious, albeit unsuccessful, tax reform initiative: the amalgamation of the three tax collection agencies - Customs, Excise and Inland Revenue - into a single revenue authority.

- In January Ranil Wickremesinghe again became prime minister. As before, the president - now Maithripala Sirisena - was from the SLFP. Wickremesinghe, however, enjoyed more autonomy over economic policy. He appointed an independent minister of finance and a career public servant took over as secretary to the ministry. The new finance team has exhibited considerable enthusiasm for raising revenue. Although many of their proposals have been introduced hastily and later withdrawn in the face of vigorous political opposition, they have taken sufficient emergency measures to halt and perhaps reverse the long decline in the tax take. ${ }^{46}$

There is then convincing evidence that the absence of powerful ministers of finance has undermined revenue collection.

\section{Lock-in to import taxes}

Levies on international trade have been the prime revenue source for the rulers of Sri Lanka for centuries. The structure of the plantation export economy encouraged an emphasis on trade taxes: the ratio of international trade to GDP was high, and that trade largely comprised highly visible bulk commodities - tea and rubber out, food grains and consumer goods in routed through Colombo port (Section 2). Import taxes have dominated. Colonial administrations understandably refrained from taxing plantation exports. The first post-

46 The emergency measures include a one-off extra profit tax in 2015, an increase in the standard Value Added Tax (VAT) rate, and a large increase in import duties on motor vehicles. The tax take has increased slightly from a low of $11.3 \%$ of GDP in 2014 
independence administration had different interests. Between 1948 and the early 1980 s plantation exports were taxed heavily, and at some points generated more revenue than import duties (Section 2). However, the taxable plantation surplus gradually shrank and eventually disappeared. From the early 1980s taxes on imports again became the main single revenue source (Section 5). It would be tempting to assume that this high dependence on import taxes is a natural consequence of the structure of the economy, or of organisational and policy inertia. Neither assumption is justified. The lock-in to import duties is to a large degree a result of political choices. To explain this slightly complex story, let us begin with the information in Table 3: a comparison of the main sources of government revenue at the end of the (pre-World War Two) colonial period (1938/9), and today (average 2011-14).

Table 3 Major sources of government revenue (\% of total), 1938/9 and 2011-14*

\begin{tabular}{|c|c|c|}
\hline & $1938 / 9$ & Average 2011-14 \\
\hline Taxes on imports** & $47 \%$ & $43 \%$ \\
\hline Total income taxes & $15 \%$ & $\begin{array}{l}19 \% \text { (comprising } 13 \% \text { from personal and } \\
\text { corporate income tax and } 6 \% \text { from taxes } \\
\text { on interest earned on bank deposits) }\end{array}$ \\
\hline Excise taxes on liquor and tobacco & $13 \%$ & $13 \%$ \\
\hline Social security contributions & $1.9 \%$ & $1.3 \%$ \\
\hline $\begin{array}{l}\text { VAT and other taxes levied on } \\
\text { domestic sales }\end{array}$ & - & $15 \%$ \\
\hline $\begin{array}{l}\text { Surplus from public sector income- } \\
\text { earning activities }\end{array}$ & $\begin{array}{l}18 \% \text { (mainly land sales, port, post } \\
\text { office, electricity and railway) }\end{array}$ & (large deficits) \\
\hline \multicolumn{3}{|c|}{$\begin{array}{l}\text { * Sources: Snodgrass (1966: 385-6); Sri Lanka Ministry of Finance (2015: 49); Sri Lanka Ministry of Finance (2016: 73-4); } \\
\text { and Central Bank of Sri Lanka (2015: table 101). Note that the figures for 2011-14 are from the Annual Reports of the } \\
\text { Ministry of Finance, and based on a substantive classification of revenue sources. By contrast, the figures in Table 2, from } \\
\text { the Annual Reports of the Central Bank, are based on a formal classification of revenue sources. They provide a very } \\
\text { misleading impression of the extent of taxation of imports. The import duties that are listed in the Central Bank reports } \\
\text { account for only about } 20 \% \text { of the taxes that are actually levied on imports. } \\
\text { ** The figure for } 1938 / 9 \text { refers to import duties, and the figure for } 2011-2104 \text { to all taxes levied on imports, including VAT, } \\
\text { excises on petroleum and cars, the Nation Building Tax, the Ports and Airports Development Levy, the Special Commodity } \\
\text { Levy and the Cess Levy. }\end{array}$} \\
\hline
\end{tabular}

Although blessed with easy import revenue, colonial governments did not fail to develop other revenue sources. More or less complete internal self-government was introduced in 1931, with a new State Council elected by universal suffrage. In 1932 the State Council introduced an income tax along British lines, and an Income Tax Department to assess and collect it (Section 2). As the figures in Table 3 indicate, the main differences between the late colonial period and today are that: (a) public sector enterprises formerly generated significant surpluses, whereas today they are the source of large deficits; and (b) the resultant gap is in large degree covered by VAT revenue. It is, however, the similarities between the two periods that are most striking: the continued high dependence on taxes on imports; the importance in both cases of taxes falling directly on consumers, especially excise taxes on liquor and tobacco; the near-absence of wealth taxes; and the minor role of taxes on income. ${ }^{47}$ Note also that social security contributions are even smaller today than in 1938/9, and that a third of income tax revenue collected today comes from a levy on bank interest, collected on a withholding basis by the banks. Contemporary governments have no greater capacity than did the 1938 colonial government to record the income of companies and wealthier individuals, assess them for income tax, and collect that tax. In fact, if we then take into account the decline of imports relative to other components of the national economy since 1938, it appears that the capacity (or willingness?) to tax income has declined since the colonial period. In 1938/9, total imports were valued at 36 per cent of GNP (Snodgrass 1966; Central Bank of Ceylon 1974). Today (2011-14) they account for 26 per cent of GDP. ${ }^{48}$

There are no significant wealth taxes at either point.

And $27 \%$ of GNI. Figures from Central Bank of Sri Lanka (2015). 
Between these two points in time, the base on which taxes on imports could be collected has thus shrunk relative to other components of the national economy. Yet taxes collected on imports account for almost as high a proportion of revenue today as they did in 1938. This shift to a higher dependence on import taxes, relative to the potential tax base, is the mirror image of the failure to expand the taxation of income (or wealth). How do we explain this failure?

There is one particular part of the story that merits mention: governments headed by President Mahinda Rajapakse (2005-2015), both responding to and encouraging intensive lobbying from the private sector, introduced a range of new charges and surcharges on imports that were intended to protect local business from import competition. ${ }^{49}$ There is, however, a larger and more complex story about the interaction of politics and institutions, which can best be introduced by comparing the Colombo headquarters of the two main revenue-collecting organisations: the Customs Department and the Inland Revenue Department.

The Customs Department occupies a spacious new building with generous staff facilities and capacious executive offices. The staff are relatively well rewarded, not least because they receive substantial bonuses from seizures of illegal imports. The senior staff, who are almost entirely male, ${ }^{50}$ exude self-confidence. They are often named in newspapers, mainly in connection with detections of attempted smuggling or illegal imports, including drugs. They report that they are consulted by government in advance of changes in customs rates or policies. The Customs Department collected 55 per cent of total tax revenue in 2014. By contrast, the Inland Revenue Department (IRD), operating from an old shabby and somewhat cramped headquarters building, collected 35 per cent. ${ }^{51}$ The senior staff of the IRD do not exhibit the self-confidence and authority of their peers at the Customs Department. ${ }^{52}$ There are no generous bonuses to be earned in the IRD, and the consensus among those I have consulted is that illegal earnings are unlikely to be high. Senior IRD staff report that they are not consulted by government before changes in tax policy. The IRD Annual Performance Report follows the established factual reporting format. Customs have a much better command of contemporary managerial style. Their Annual Performance Report is twice the length of the IRD report, is better designed, and is to some degree organised around quantitative information on performance targets and achievements for individual operational units. The Customs Department is more active in providing staff training, and, unlike the IRD, has a separate Directorate for this purpose.

These two organisations have not always been positioned this way in terms of power and prestige. Historically the Inland Revenue Department was the more senior of the two. In Sri Lanka, as formerly in the UK, ${ }^{53}$ Customs was viewed almost as a blue collar occupation, performing policing tasks that required little analytic capacity. It was the white collar Inland Revenue Department that required analytic skills, recruited the academic high flyers and enjoyed professional prestige. In the immediate post-independence period in Sri Lanka, the Inland Revenue Department was typically the third career choice - after the Civil Service

\footnotetext{
49 It introduced a range of new charges, most of them surcharges on import duties - the Nation Building Tax, Ports and Airports Development Levy, Special Commodity Levy and Cess Levy - that collectively resulted in a major shift towards a protectionist economic policy.

50 According to the 2014 Annual Report of the Customs Department, there were only three women among the thirty-five most senior posts, and they were all working in Human Resource Management or Employee Service (Sri Lanka Customs 2015). All the people who appear in photographs on Facebook postings related to the Customs Department are male.

51 The Excise Department collected 7\% of the total tax revenue, and most of the remainder came from the Telecommunication Levy (Sri Lanka Ministry of Finance 2015).

52 There are noticeably more women among the senior ranks of the IRD than in Customs. In 2014, four of the eight most senior posts were occupied by women. At the next level down, the rank of Senior Commissioner, there were six women and fifteen men (Sri Lanka Department of Inland Revenue 2015).

53 Before the UK Customs and Excise and Inland Revenue Departments were merged in 2004.
} 
(later Administrative Service) and the Foreign Service - for those with the highest grades in the public service entrance examination. How did the prestige and power of the two departments come to be inverted? Part of the explanation is that, as post-1977 governments lost interest in taxing income and wealth, they also lost interest in trying to protect the organisational quality of the Inland Revenue Department. It was instead infected by the general deterioration in the quality of recruitment, management, discipline and morale that affected almost the entire public service. ${ }^{54}$ But why did the same not happen in the Customs Department, at least to the same extent?

The answer is that, for a combination of reasons, the Customs Department has become a strategic organisation from the perspective of governments: an organisation from which they require competence and over which they need to exercise control. ${ }^{55}$ Three of the reasons are straightforward:

- After the outbreak of separatist conflict in the early 1980s, Customs assumed important security functions that they hitherto lacked.

- There is scope for large-scale illegal earnings in Customs; politicians in power seek a share.

- More recently, the big growth of the trans-shipment trade and large-scale investments in container terminal facilities (Section 5) have increased the importance of an effective Customs Department.

The fourth reason for the strategic role of the Customs Department is a little more complex, and related to the character of contemporary interest group politics.

The working-class-based trade union and Marxist political movements that were so prominent in the mid-twentieth century have largely disappeared (Section 4). This does not mean that governments now face little opposition from societal groups. There are many interest groups. Some are formidably organised. Virtually all of them represent sectional interests within the wealthier half of the population. Top of the list is the General Medical Officers Association (GMOA), which has proven itself remarkably effective in protecting and enlarging the privileges of doctors employed in government facilities. The GMOA is quickly able to bring the public health service to a halt. A wide range of other professional associations exercise similar power on a reduced scale. Cricketing bodies are well represented in policymaking. All governments are mindful of the need to mollify elected MPs. Since the creation of a powerful executive presidency in 1978, most MPs have little influence on policymaking and a decreasing attachment to any particular political party. They can cause a great deal of trouble for governments if not given continual sweeteners.

There is indirect evidence for this in contemporary differences between the two Departments in the ethnic composition of their senior staff cadres. Of the 29 most senior people in the Inland Revenue Department in 2014, 28 have Sinhalese names (Sri Lanka Department of Inland Revenue 2015). By contrast, only 23 of the 35 most senior people in the Customs Department in 2014 have Sinhalese names, and 12 have Tamil or Muslim names (Sri Lanka Customs 2015). The population of Sri Lanka is about $70 \%$ Sinhalese. Sinhalese totally dominate the senior ranks of the Inland Revenue Department, but are proportionately represented in the Customs Department. Historically, various minority ethnic groups were over-represented at more senior levels of the public service, and in more specialist and professional posts. Fuelled by political competition between ethnic groups and then by separatist conflict, that over-representation has generally gone into reverse in recent decades. Both electoral pressures and the shift to a more clientelistic political system have favoured recruitment of Sinhalese. The fact that these pressures have not overwhelmed the Customs Department suggests that governments have made efforts to protect against complete politicisation, in order to maintain organisational competence.

55 The Customs Department is not particularly efficient according to conventional criteria. e.g. today trade facilitation is the primary objective of Customs organisations worldwide. Among other things, this implies suspending automatic physical inspections of every trade consignment, permitting 'trusted traders' to move their goods fast across borders and through ports on the basis of pre-cleared electronic documentation and statistical risk analysis of the likelihood of false declarations. Although the Sri Lanka Customs Department acknowledge this as an important objective, as of mid-2016 they were still physically inspecting every consignment. 
Governments routinely use exemptions from a range of import duties on motor vehicles to sweeten these middle-class interest groups. Given the large consumer appetite for motor vehicles ${ }^{56}$ the near-absence of any domestic vehicle assembly, and the relatively high overall level of import protection, these exemptions are very valuable. In 2014 duties of various kinds on motor vehicle imports accounted for 27 per cent of the total revenue collected by the Customs Department (Sri Lanka Customs 2015: 13). Beneficiaries routinely sell the vehicles imported with the benefit of exemptions, and go back for more. Because the rules about who may benefit from which exemptions are complex and frequently changed, Customs staff in practice have a great deal of discretion over the charges they levy on imported vehicles. In turn, politicians in power can influence the way in which that discretion is exercised. No government would want a Customs Department that was so incompetent or corrupt that it was not a reliable instrument for the exercise of this kind of political patronage.

In sum, the apparent lock-in to reliance on import duties for revenue is not the result either of the structure of the economy (i.e. a high ratio of international trade) or of organisational and policy inertia. It reflects two broad political factors, that are almost opposite sides of the same coin: the clear reluctance of governments, especially since 1977, to tax income and wealth (Section 9); and the growth of the power and prestige of the Customs Department relative to the Inland Revenue Department. From the perspective of government, Customs has become the department that delivers a range of valuable services (including security and the management of an important mechanism of political patronage). That in turn interacts with some concern within government to preserve the institutional integrity of the Customs Department; willingness to permit high earnings within the Department; high staff quality; the inclination of government to consult with Customs over policy issues; and a tendency to allocate to Customs a high share of new revenue-raising instruments. ${ }^{57}$

\section{Concluding comments}

It was not only the relative ease with which the plantation export economy could be taxed that generated a high tax take in Sri Lanka in the mid-twentieth century. The revenue system was in some respects quite advanced: an income tax had been raising significant revenue since 1932; the senior staff of the Inland Revenue Department were part of the public service elite; self-assessment for income tax was introduced as early as 1972/3; and a relatively sophisticated Business Turnover Tax, with some features of a VAT, was in place from 1963 until it was replaced by VAT in 1998 (de Silva 1992: 193). ${ }^{58}$ However, the contemporary revenue system looks antiquated. At the macro level, it generates only about half the revenue one would expect (Introduction), ${ }^{59}$ and bears excessively heavily on imports (Section 8).$^{60}$ At the level of detail, it is deficient in many respects: most wholesale and retail activity was exempted from VAT until 2014 (IMF 2014: 10); there are an excessively large number of VAT rates, which are changed frequently; tax exemptions have multiplied (Section

$56 \quad$ In the years 2012-2014, on average 412,000 motor vehicles were imported annually, to serve a total population of just over 20 million (Sri Lanka Customs 2015).

57 In 2014 import duties accounted for only $18 \%$ of the revenue collected by the Customs Department. The others were: VAT (22\%), Excise Duty (22\%), Port and Airport Development Levy (15\%), Special Commodity Levy (11\%), Import Cess (8\%) and Nation Building Tax (5\%) (ibid).

58 The replacement of the Business Turnover Tax with VAT in 1998 remains controversial. It was the result of strong pressure from the IMF, with considerable local professional opposition. The outcome was a relatively incomplete and ineffective VAT.

59 Correspondingly, the shadow economy - economic activity that is deliberately concealed from government authorities is estimated to be unusually high in Sri Lanka. Using data for 1999-2006, the shadow economy was estimated to amount to about $44 \%$ of GDP in Sri Lanka, compared to $22 \%$ for India, around $36 \%$ for Bangladesh, Pakistan and Nepal, and an average of $36 \%$ for all developing countries studied (Schneider et al. 2010).

60 Note, however, that the cost of revenue collection in Sri Lanka is relatively low, and has long been so (Jenkins 1988). This is likely because of the high level of unchecked self-assessment by taxpayers, and, more generally, the limited resources put into revenue collection. 
6); self-reporting by taxpayers has not been balanced by a reasonable degree of auditing of returns by the tax authorities, such that evasion is relatively easy; tax collection staff appear to enjoy a high degree of discretion, and focus their efforts on a relatively small number of registered taxpayers; until recently, tax amnesties were 'granted with almost monotonous regularity', but did not generate significant additional revenue (Waidyasekera 2012: 333); there are far too many different taxes and levies; $; 1$ at the end of 2014, 503,000 individuals, less than 6 per cent of the labour force, were registered with the Inland Revenue Department for personal income tax (Sri Lanka Department of Inland Revenue 2015: 15) - partly because public servants have been almost entirely exempt from personal income tax since 1979; rules, laws and treaties for taxing foreign investors and controlling tax evasion through transfer mispricing in international economic transactions have received little attention; ${ }^{2}$ undervaluation of imports is believed to be widespread; and the revenue collection departments have not had good access to third-party information through systematic linkages with other relevant government departments, like Electricity, Telecommunications, Land Registry and Motor Vehicles. ${ }^{63}$

The broad explanation for all this is that, since 1977 in particular, governments have been willing to allow the revenue system - especially the Inland Revenue Department - to decay, because this has been in the immediate material interest of the wealthier sections of the population: those who pay little or no direct tax on their (fast-growing) income, property values and other wealth, and are not directly impacted by the degeneration of under-funded public education, health and social protection systems. The current prime minister, in power since January 2015, has long been aware of and concerned about revenue performance. It has become urgent because commercial creditors have become wary of lending even more to a government that is still running large fiscal deficits and has seemed unable to stem the revenue decline. The new government has responded with emergency revenue-raising measures. These have had some success, but still face very strong political and public opposition. ${ }^{64}$ There is very little public understanding of or sympathy for the government's fiscal position. Taxes are never popular, but, for historical reasons, the Sri Lankan electorate exhibits a particularly deeply-embedded hostility (Section 2). There is clearly no easy way of overcoming such resistance. But a policy measure suggested by the 1968 Taxation Enquiry Commission, and still not implemented, might have some traction.

The Commission concluded that taxation in Sri Lanka was badly organised. The three revenue collection Departments - Customs, Excise and Inland Revenue - were under the general authority of the Treasury, but operated independently of one another. Further, there was no appropriate forum within the apparatus of government to debate tax policy options. The Commission recommended the creation of a Directorate of Revenue to oversee the collection process, with a director general directly responsible to the minister of finance. The director general would also chair a Permanent Taxation Commission, which would advise the minister on tax policy - and include non-official members (Government of Ceylon 1968: 507). The 1986 and 1990 Taxation Enquiry Commissions made very similar recommendations

$61 \quad$ In his 2016 Budget Speech, the finance minister claimed that there are 35 separate taxes and levies.

62 e.g. it was only in 2008 that Sri Lanka promulgated regulations that would enable the Inland Revenue Department to take steps to try to limit the widespread practice of transfer mispricing in international economic transactions. Transfer mispricing is a major source of tax avoidance and evasion globally. In 2013, KPMG reported that the regulations were not yet being enforced, and that remains the case today. By contrast, India passed its first law on transfer mispricing in 2001. In the same year, under the Income Tax Ordinance, Pakistan introduced a 'general anti-avoidance rule' that gives the revenue authorities power to deal with transfer mispricing. A 2016 Action Aid report lists those lower-income countries in Africa and Asia that have signed the largest number of restrictive tax treaties that are likely to severely limit their taxing powers in relation to foreign investment. Sri Lanka - a country well-endowed with distinguished lawyers comes close to the top of the list (Action Aid 2016).

63 The Inland Revenue Department is acquiring a new information system that will permit the automation of many existing operations and enable others to be performed for the first time, including real-time linkages to databases used by the Customs Department and other government departments. Progress is very slow.

64 e.g. 27 of the revenue proposals included in the finance minister's 2015 Budget Speech were not implemented because of opposition. 
(de Silva 1992: 196-7; Waidyasekera 2012). They were never accepted. The organisation of revenue collection remains the same today as it was in the late colonial period. ${ }^{65} \mathrm{~A}$

Permanent Taxation Commission, with a mandate to report to parliament as well as to the minister of finance, might provide a useful channel to encourage Sri Lanka's voters and politicians to begin treating raising revenue as a serious issue. 


\section{References}

ActionAid (2016) Mistreated. The Tax Treaties that are Depriving the World's Poorest Countries of Vital Revenue, ActionAid

Central Bank of Sri Lanka (2015) Annual Report 2015, Colombo: Central Bank of Sri Lanka

Central Bank of Ceylon (1974) Annual Report 1973 Colombo: Central Bank of Sri Lanka

de Silva, K.M. (ed) (1973) History of Ceylon, Volume 3, From the Beginning of the Nineteenth Century to 1948, Peradeniya: University of Ceylon

de Silva, R.G.L. (1992) 'Sri Lanka Taxation Commission Report', Bulletin for Fiscal Documentation 46(4): 192-197

Dharmasena, K. (1980) The Port of Colombo 1860-1939, Colombo: Lake House Printers and Publishers

Frankema, E. (2010) 'Raising Revenue in the British Empire, 1870-1940: How "Extractive" Were Colonial Taxes?', Journal of Global History 5(03): 447-477

Gerring, J., Ziblatt, D., Gorp, J. and Arevalo, J. (2011) 'An Institutional Theory of Direct and Indirect Rule', World Politics 63(3): 377-433

Government of Sri Lanka (1974) Report of the Commission of Enquiry on Agency Houses and Brokering Firms, Colombo: Government of Sri Lanka

Government of Ceylon (1968) Report of the Taxation Inquiry Commission, Colombo: Government of Ceylon

IMF (2014) Sri Lanka. 2014 Article IV Consultation and Second Post-Program Monitoring Discussion -Staff Report; Press Release, IMF Country Report 14/285, Washington DC: International Monetary Fund

Jenkins, G.P. (1988) Tax Changes before Tax Policies: Sri Lanka 1975-1988, Cambridge MA: Harvard Institute for International Development

Jupp, J. (1978) Sri Lanka: Third World Democracy, London: Cass

Kearney, R.N. (1974) The Politics of Ceylon (Sri Lanka), Ithaca: Cornell University Press

_ (1971) Trades Unions and Politics in Ceylon, Berkeley: University of California Press

Lange, M. (2009) Lineages of Despotism and Development: British Colonialism and State Power, Chicago III and London: University of Chicago Press

Maddison, A. (n.d.) 'Historical Statistics for the World Economy', from <http://www.google.co.uk/search?q=\%22historical+statistics+for+the+world+economy $\% 22 \&$ ie=utf-8\&oe=utf-8\&aq=t\&rls=org.mozilla:en-US:official\&client=firefox-a>

Manor, J. (ed) (1984) Sri Lanka in Change and Crisis, London and Sydney: Croom Helm 
Minh Le, T., Moreno-Dodson, B. and Bayraktar, N. (2012) Tax Capacity and Tax Effort. Extended Cross-Country Analysis from 1994, Policy Research Working Papers, Washington DC: World Bank

Moore, M. (2008) The State and Peasant Politics in Sri Lanka, Cambridge: Cambridge University Press

_ (1993) 'Thoroughly Modern Revolutionaries: the JVP in Sri Lanka', Modern Asian Studies 27(3): 593-642

_ (1989) 'The Ideological History of the Sri Lankan "Peasantry"', Modern Asian Studies 23(1): 179-207

Pessino, C. and Fenochietto, R. (2010) 'Determining Countries' Tax Effort', Hacienda Public Espanola/Revista de Economia Publica 194(4): 65-87

Republic of Sri Lanka (1977) Budget Speech 1978, Colombo: Department of Government Printing

Roberts, M. (1982) Caste Conflict and Elite Formation: The Rise of a Karava Elite in Sri Lanka, 1500-1931, Cambridge: Cambridge University Press

_ (1973) 'Land Problems and Policies, c 1832 to c 1900', in K. M. de Silva (ed), History of Ceylon Volume 3, Peradeniya: University of Ceylon Press Board

Schneider, F., Buehn, A. and Montenegro, C.E. (2010) Shadow Economies All over the World. New Estimates for 162 Countries from 1999 to 2007, Washington DC: World Bank

Singer, M.R. (1964) The Emerging Elite. A Study of Political Leadership in Ceylon, Cambridge MA: MIT Press

Snodgrass, D.R. (1966) Ceylon: An Export Economy in Transition, Homewood III: Richard D. Irwin Inc.

Sri Lanka Customs (2015) Annual Performance Report 2014, Colombo: Sri Lanka Customs

Sri Lanka Department of Inland Revenue (2015) Performance Report of the Commissioner of Inland Revenue 2014, Colombo: Department of Inland Revenue

Sri Lanka Ministry of Finance (2016) Annual Report 2015, Colombo: Ministry of Finance

_ (2015) Annual Report 2014, Colombo: Ministry of Finance

Venugopal, R. (2011) 'The Politics of Market Reform at a Time of Civil War: Military Fiscalism in Sri Lanka', Economic and Political Weekly 46(49): 67-75

Waidyasekera, D.D.M. (2012) Taxation, Fiscal Policy and the Economy in Sri Lanka, Colombo: Stamford Lake

Wickremeratne, L.A. (1973) 'The Emergence of a Welfare Policy, 1931-1948', in K.M. de Silva (ed), History of Ceylon, Volume Three, Peradeniya: University of Ceylon 
World Bank (2015) Sri Lanka - ending poverty and promoting shared prosperity: a systematic country diagnostic, Washington DC: World Bank

_ (2012) Creating Fiscal Space through Revenue Mobilisation, South Asia Economic Focus, Washington DC: World Bank

- (2011) Transforming School Education in Sri Lanka: From Cut Stones to Polished Jewels, Washington DC: World Bank 


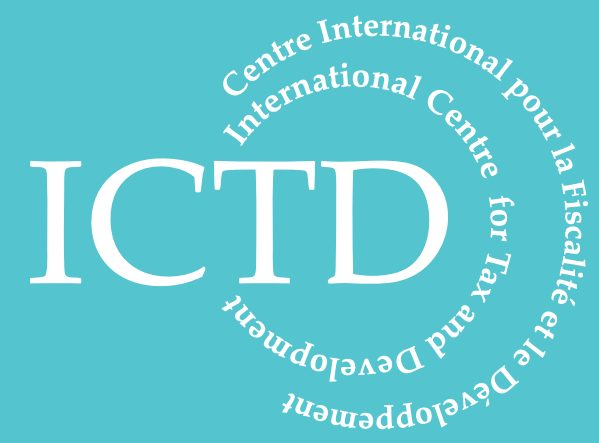

International Centre for Tax and Development at the Institute of Development Studies

Brighton BN1 9RE, UK

T: +44 (0) 1273606261

F: $+44(0) 1273621202$

E: info@ictd.ac

www.ictd.ac 